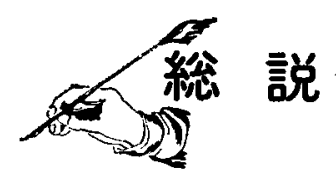

\title{
フィールドイオンマイクロスコピー の最近の進歩
}

\section{1 まえがき}

フィールドイオンマイタロスコープ (FIM と略す) が E.W. Müller により 1951 年に発表1)されて以来 23 年余の間の進歩は著しい\&のがある. 先ほど 1968〜70 年間に FIM 関係の著書が 3 冊も出版され ${ }^{224)}$, 歴史的 な発展過程法もちろん，その頃までの進歩のほとんどが そこに記述されている．また筆者は 1972 年日本化学会 秋季年会で, その後の成果上将来の力向について講演し たがら゙,さらに 1973 年 8 月に Müller の研究室のある米 国ペンシルバニヤ州立大学で開催された第20回電界放射 シンポジウムに 10 年ぶりで参加し*2，この1年余の間 の進歩に触れることができた。また 13 年前に筆者の作 った装置が, Miiller の研究室内の元と同じ場所に，そ のまま保存されており，彼らの好意に感激するとともに 10年余の間の急速な発展にはまったく驚嘆のほかはなか った.

\section{FIM. の概説}

FIM に関する初歩的解説はわが国だも多く書かれて いるので6) こ)，ここではごく概説にとどめる．W，Mo, $\mathrm{Pt}, \operatorname{Re} な と ゙ の$ 耐熱金属の針状試料 (tip という) の先端

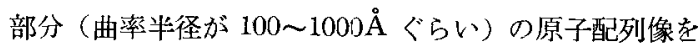
観察するような，初歩的な目的のためには図1(a)のよ らな簡単なガラス製で十分ふある.（b）のよらに付属装

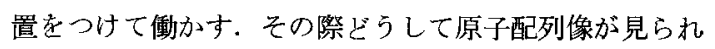
るかといら原理について Müller らは（c）のような考え 方を採っている.すなわち, tip 先端部分を拡大して構

* 名古屋工業大学 (名古屋市昭和海器所町)

*1 わが国からは，阪大産研の中村腾吾教授と 2 人のみ参加した。

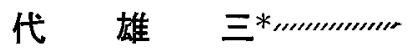

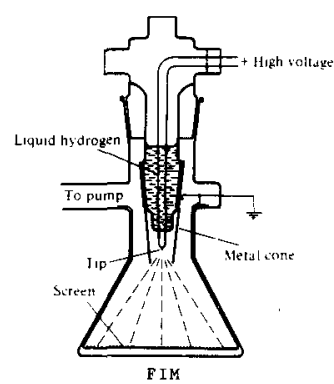

(a)

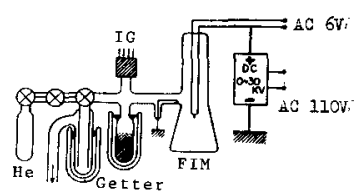

(b)

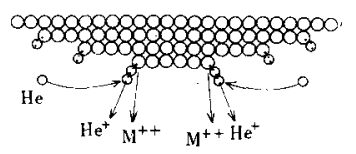

(c)
図 1 (a):FIM 本体, (b) : FIM O付属装置

(c) : FIM の原理 (電界吸着説) (Müller, Tsong) 成原子の 1 個 1 個が区別できるほどにしたとする。 tip に正の高電界をかける.そこへ結像ガス*2として入れて ある $\mathrm{He}$ (約 $10^{-3}$ Torr) の原子が近ゔくと, tip 表面 の原子面の縁をなしているような突出原子のところは特 に電界強度が大きいので，その $\mathrm{He}$ 原子は分極状態で吸 着される.その吸着された $\mathrm{He}$ 原子上にさらに他の $\mathrm{He}$ 原子が双極子間結合の形で吸着すると，後者の $\mathrm{He}$ 原子 は正イオンとなり（He 原子の大きなイオン化電位約 $24.5 \mathrm{eV}$ 加考えて, 少くとも tip 表面では $4 \mathrm{~V} / \AA$ 济以上 の電界強度となる)，tip に反発されてスクリーンに向け て飛び，そこに tip 表面の突出金属原子に対応した像を つくる.このような考え方を電界吸着説とい5 ${ }^{10)}$. 6ち ろん，他のいろいろな原子や分子が tip 表面に吸着して いるときは，適当な電界強度でそれらが正イオンとなっ たり，また試料表面原子と錯体イオンを作ったりして脱 離するので，これを区別して電界脱離 (FD と略す) と

*2 結像カスとしては He 以外に $\mathrm{Ne}, \mathrm{Ar}, \mathrm{H}_{2}$ およびそれらの混合気体 か使用される。 
いう。ささらに高電界になると $\mathrm{tip}$ 表面原子自体がイオン になり飛び去るのでこれを電界蒸発（FEV と略す）と いう。したがって結像がスがイオン化するより低い電界 で試料がイオン化しては試料のイオン像はえられない。 また非常にイオン化電位の低い気体分子（原子）

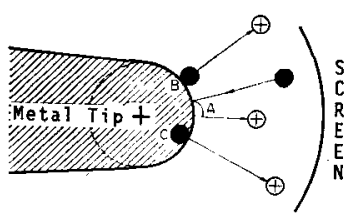

(a)

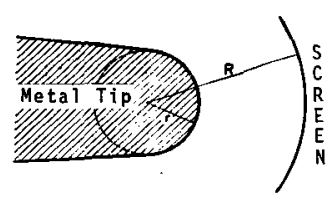

(b)
図 2 (a): お㐫 3 種類の FI, A; 気体原子, $\mathrm{B} ;$ 吸着物, C; tip 表面原子 (b) : FIM の倍率の算出

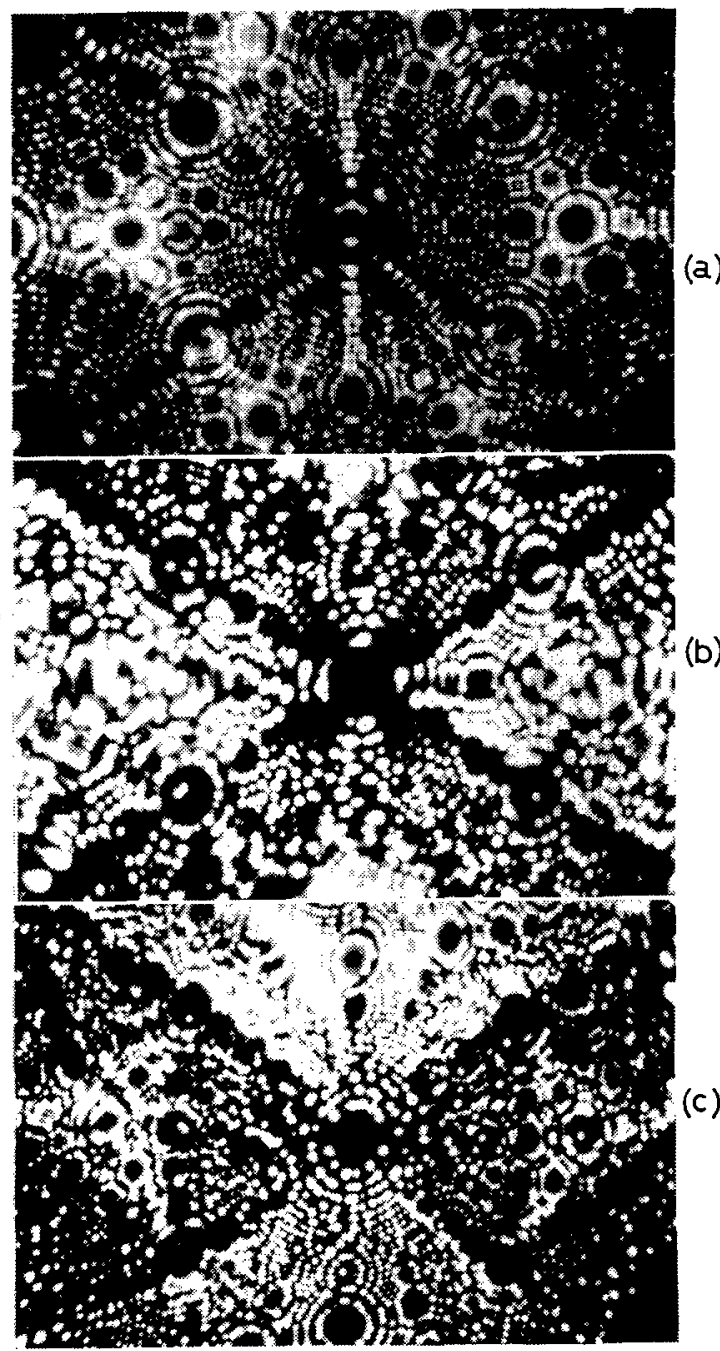

図 3 (a): W, (b): Mo, (c): Ta の He イオン像 （屋代, 阿部)
先端に到着しないらちに，むたは到達して吸着されない うちに正イオンになる，以上の現象をまとめて電界イオ ン化 (FI と略す) といっている. 図 2 (a) にそれを示 した. もし tip 先端を球面とし, その半径 $r=500 \AA$, tip とスクリーン間の距離 $R=7.5 \mathrm{~cm}$ とすれば，倍率 $M=R / \beta r=7.5 / \beta \times 500 \times 10^{-8}$ で， $\beta=1.5 \sim 1.8$ の補正 項であるから，M〜10 となる. 図 2 (b) 注その説明図 である. 図3にはこのようにして観察した W，Mo，Ta の He イオン像を示した。、ずれも bcc 金属で，像の 中央は（011）面である，FIM は表面物理や金属学の方 面では，非常に有力な研究装置として利用され多くの研 究がある. 最近 Müller らによってイオン像として見え る1 個 1 個の原子をパルス FEV によりイオンとして取 り出し，それを質量分析 (MS と略す) して同定する， いわゆる原子プローブ FIM (APFIM と略す) が開発 されたので ${ }^{11}$ ，急激に化学者の注目をも引くようになっ た。この総説では，本誌の性格を考慮して，APFIM や その前身である FIMS の最近の進歩と, FIM の他の化 学分野への応用例について述べることにする。

\section{APFIM}

化学者の長年の夢の 1 つは，原子や分子を直接観察す るとともに，その 1 個 1 個の原子の同定ができることで あった．特殊な条件下で，乙かも限られた原子種の笨囲 とはいえ，この夢の一部が実現されたことは偉大な進歩 といってよい，この同定に使用された始めのものは飛行 時間型 MS であった。この型は化学方面でもすでに用 いられており ${ }^{12)}$ ，その原理は簡単なので省略する．しか し，おもな改良点注（1）FIM 像を観察しながら分析し たい1つの原子を選ぶことができる.（2）そこに $10^{-9}$ 秒程度の1個の高電界パルスをかけてその原子を FEV させる. (3) FIM 像を与える結像ガスは 10-4Torr 程度 連続導入しながらも，飛行へオンの道筋の部分は $10^{-10}$ Torr 程度の超高真空にしている. (4) 検出器としての 二次電子増倍管は $10^{10}$ 程度のダインを持っている. (5) tip にかけられたパルスと, 検出器に到達した 1 個のイ オンの電荷を堌幅して同じォシシにかけ，その時間差 から $m / n e$ をうる。图 4 (a) はその初期の装置であ $y^{11)}$ ，(b)，(c) は最近の装㯰である ${ }^{13)}$. 分解能は $1 / 250$ とされている. tip 先端から $10^{-9}$ 秒パルスによりイオン 化され飛び出すイオンのエネルギーにはいろいろな理由

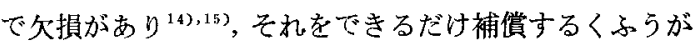
されている，また（b)，(c) からわかるように, 検出用 にダブルチャンネルプレートが使用され，1個のイオン の衝突により約百万個の二论電子が発生し，蛍光板を光 らせるので，これらの MS を直接写真にとることがき る.このようなチャンネルプレートの利用は FIM には 

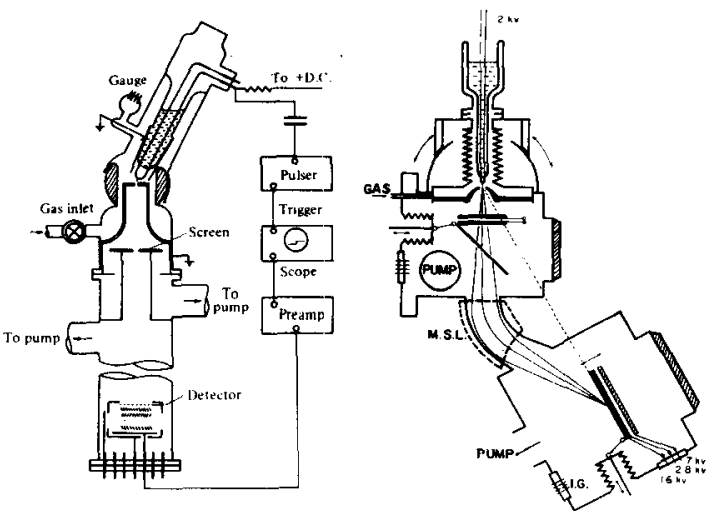

(a)

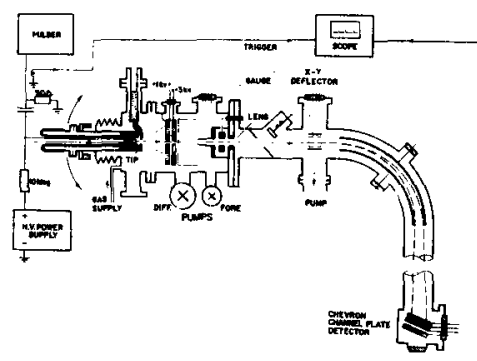

(c)

図 4 APFIM (a)：初期の装置 (Müller et al.) (b), (c) : 最近の装置 (Müller et al.)

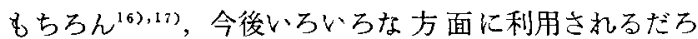
$5^{18)}$.

APFIM は現在は主として金属学の問題に利用されて いるが，FIM で原子像が観察されうる根本的な問題に も多くの情報を与えて㧍り，その結果，前述の電界吸着 が採用されているのである゙0).したがって金属表面にい ろいろな気体が吸着する問題について相当に研究例が 増しており，W， Ta， Rh, Fe, Ni, Co, Nb, Au, Ir, Pt, C と $\mathrm{He}, \mathrm{Ne}, \mathrm{Ar}, \mathrm{H}_{2}, \mathrm{O}_{2}, \mathrm{~N}_{2}, \mathrm{CO}$ などの組み合わせが 研笲されている(5),19),20)。その結果これらの金属之希が

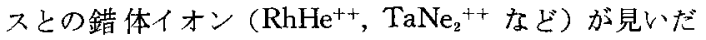
されたり，従来の熱的な実験とは合わない例を発見され ている. FIM である限り，相当の高電界がかかってい るので，そのような条件下゙のの吸着や，化学反応はこれ まではほとんど研究されて扔らす，新しい反応例が発見 される可能性は大きい。このような高電界下の反応を電 界誘起化学反応と総称しているが, 今後の新しい研究分 野となるだろう。

\section{FIMS}

普通の MS のイオン源の部分を替えて, 前述の FIM のように tip 先端の強電界により分析試料を FI 化する
型のものも非常に役だつ。この方面の研究は Inghram と Gomer によって始められた ${ }^{21)}$. しばらく中断後，Beckey $^{22)}$ と Block ${ }^{23)}$ によって再開され，扝もに有機物や 触媒反応が研究されている，MSには静電レンズ型, 磁 気セクターレンズ型, 飛行時間型, 四極電磁石型などが 使用されている．Beckey は金属㧍よびCなどの線ある いは tipの表面に，特殊处理により多数の有機物のマイ タロニードルをつくり，高電界で FI 化する方法を発明 している. 吸着層の研究, ラジカルの検出, 强電界下の 有機物イオンの構造，その分解反応機構，反応速度など 多岐にわたった長年の研究成果は彼の著書にま之められ ている. 図 5 (a), (b) に Beckey の初期の FIMS 装置 レマイクロニードルの例を示した。最近仗高温処理する
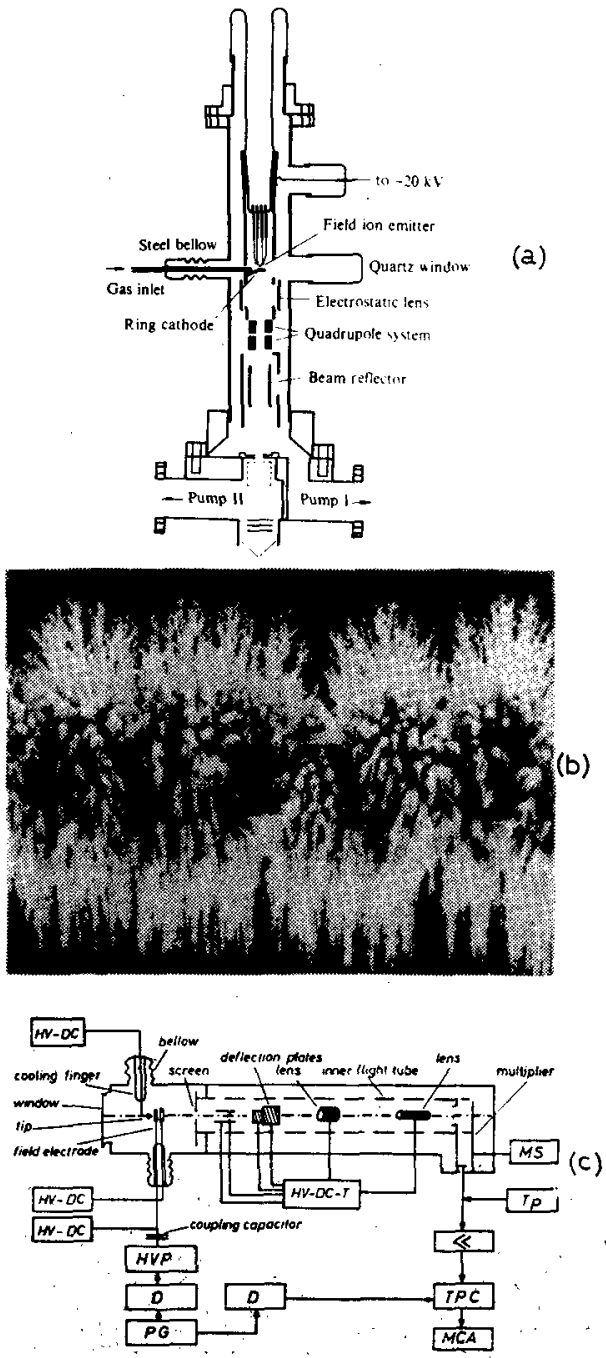

図 5 FIMS (a): Beckey の初期の装置, (b) : $10 \mu \mathrm{m}$ のタングステン上のマイクロニードル (Beckey) (c) : Block の装置の回路 
と，熱的，化学的に安定なマイクロニードルができるこ とを見いだし ${ }^{24)}$ ，この方法で FIMS やFDMS を高温 虬あ試料に対しても応用するここに成功している. Perfluorokerosene や Perfluorotributylamine にかけ，m/eの 50〜850 間に多くのピークをえ，電子 衝撃法によるMSと比較している. 将来の目的は DNA にあるという. Block らは特に触媒反応に力を入れてお り, 装置も図 5 (c)のように Müller らの AP FIMに 近くなっている ${ }^{23)}$. 最近の研究は $\mathrm{Ag}-\mathrm{O}$ 系の反応であ 万$^{25)}$, 微量の $\mathrm{H}_{2} \mathrm{O}$ の存在で, $\mathrm{Ag}$ tip 表面で $\mathrm{Ag}\left(\mathrm{H}_{2} \mathrm{O}\right)_{\mathrm{n}}{ }^{+}$ $(\mathbf{n}=1,2,3,4)$ の生成があり, 二次的に $\mathrm{AgO}^{+}, \mathrm{AgO}_{2}$ が生ずるとしている， $\mathrm{H}_{2} \mathrm{O}$ のないときは分子状 $\mathrm{O}_{2}$ 省導 入しても $\mathrm{Ag}-\mathrm{O}$ 間化合物は全然生しない. 他の気体で b $\left[\mathrm{AgX}_{\mathrm{n}}\right]^{+}$の錯体イオン $\left(\mathrm{X}=\mathrm{H}, \mathrm{CO}, \mathrm{CH}_{4}, \mathrm{~N}_{2}, \mathrm{NH}_{3}\right.$, $\mathrm{n}=1, \cdots 6$ ）が低温でも生成することを見いだしている. $\mathrm{Ag}$ 表面原子の著しい分極に原因があり，時にはイオン 状態にさえあるかもしれないと考えている。

\section{FIM の他の化学分野への応用}

\section{1 原子・分子の可視性}

上述の上5に金属表面原子は, 確かに割合值接的に 1 個 1 個の観察が可能であるが, 他の一般の原子や分子は どうであろうか? 電界電子顕微鏡*3 (FEM と略す) では, tip 表面の各部分からの電子流がそれらの部分の 仕事関数と電界強度に支配されるような像を与える。こ のとき tipに Cu-phthalocyanine を吸着させたときの 像を図 6 に示す。これが本当の分子像であるが、い

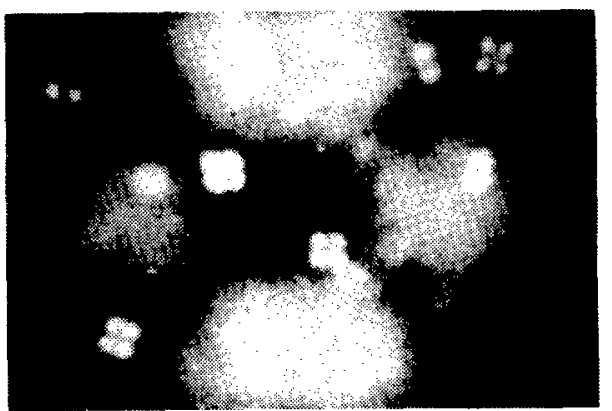

図 6 W tip 上吸着した Cu-phthalocyanine の FEM 像 (屋代)

まだに問題である．特に最近，放射電子流のエネルギー 分布の研究が盛んになり，吸着分子と基体金属閒のいる いるな電子エネルギー関係が見いだされており，この像 の解釈も再検討を必要とすることになるだろう ${ }^{26)}$. 種々 の吸着原子・分子の. FIM に上る可視性は未解決の点が 多く, Ehrlich と Hudda は $\mathrm{He}$ イオン像で $\mathrm{N} / \mathrm{W}$,

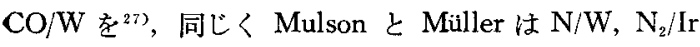

*3 FIM と反对心 tip に負の高䉓界をか弨高真空中だ tip 先端から電 子線在放山士甘をの像索観察する5).
$を^{28)}$, Holscher Ł Sachtler は N/W ${ }^{29)}$, Sugata $と$ Ishii は O/W を30)，それぞれイメージとして見いだし えたとしているが, Lewis上Gomer はArイオン像で は $\mathrm{N} / \mathrm{W}, \mathrm{CO} / \mathrm{W}, \mathrm{O} / \mathrm{W}, \mathrm{H} / \mathrm{W}$ は見えず， $\mathrm{CH}_{4} / \mathrm{W}$ は見 えるらしいといっている゙'). $\mathrm{CH}_{4} / \mathrm{W}$ については, Schmidt と Krautz の興味ある研究からは $\mathrm{CH}_{2}$ または $\mathrm{CH}_{3}$ の形でおそらくW表面を吸着移動していると考えられて Wる(2).

さらに大きな有機分子の観察む試みられている。多く の有機化合物のイオン化電位は $7 \sim 15 \mathrm{eV}$ なので普通の 手段では FI 化して飛び去ること多く, その構造観察に は特殊なくふらを要する. Mïller はまず埋込法を試み $\star^{33)}$. 図 7 (a) のよ5に tip 表面に適当な他の金属を メッキする際，有機物を同時に埋込み，FIM 内で FEV によりしだいにメッキ層をはぎとって行けば，どこかで

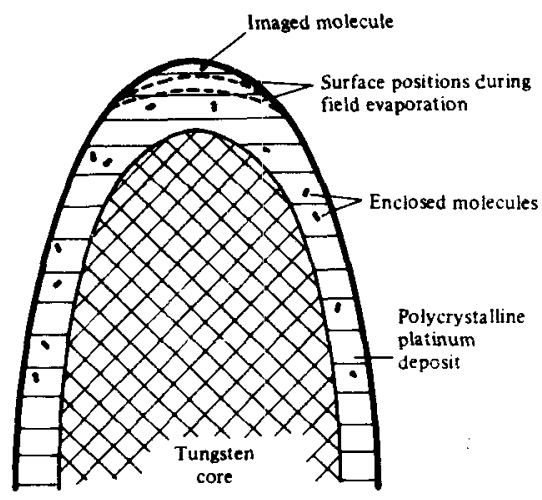

(a)

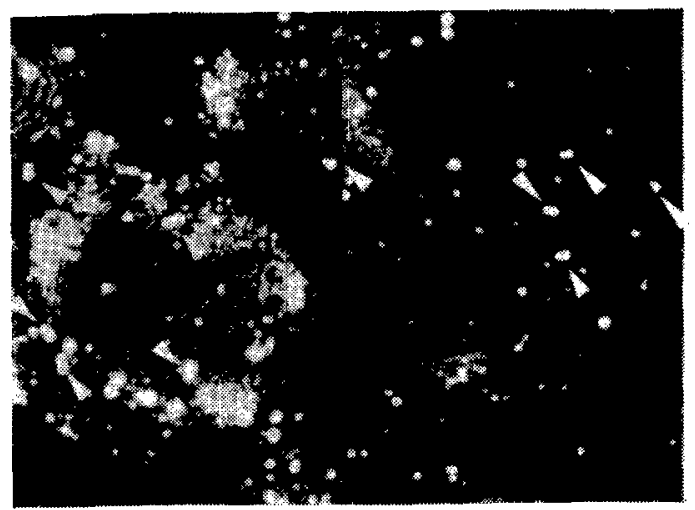

(b)

(c)

图 7 (a): 埋込み法 (Müller, Rendulic), (b) : 補酔 素I の FIM 像 (Müller, Rendulic), (c):ビタ ミン $\mathrm{B}_{12} \sigma$ FIM 像 (Müller, Rendulic)

有機物が顔を出すという予測である。(b)，(c) はこのよ うにして観察された補酵素 1 と $\mathrm{B}_{12}$ の例であるが，これ から上記化合物の既知の構造を確かめることはむずかし い. 次に Müller は金属板に: DNAをつけて掞き, FIM 内で tipにこれを押付け，DNA tip 先端に付着させ金 
属板を取り去って後, tip 婊面のイオン像を観察したの が図 8 である ${ }^{15)}$. 多少“らしきもの”が見えているが， この方面の研究む今後の大きな課題となるだろう。

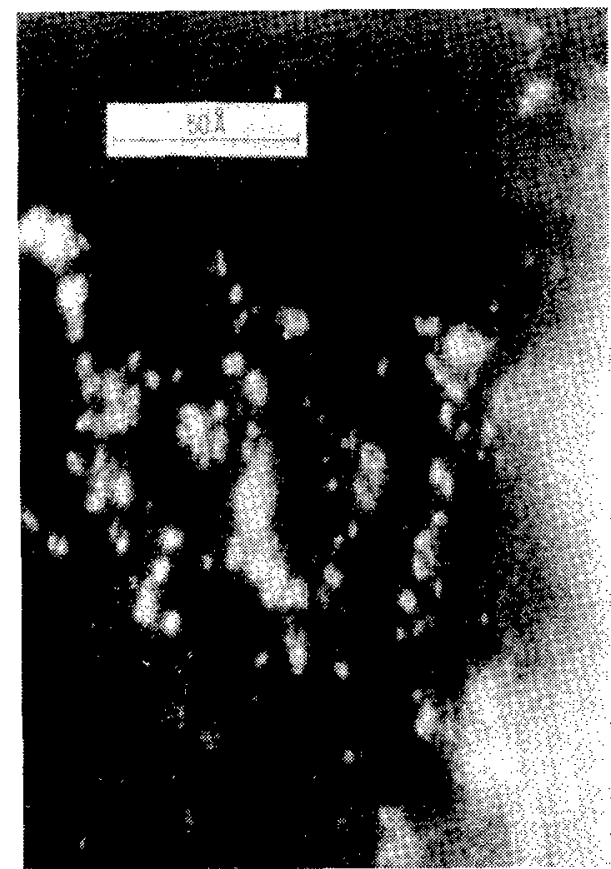

図 8 Ir tip の先端に押し付计られた DNA の水䅈 イオン像 (Müller)

\section{2 表面化学反応}

電界誘起反応については既述したが，他の簡単な気体 と tip 金属との表面化学反忘行わせるいわゆる化学吸 着や腐食の研究は, Müller によって $\mathrm{O}_{2} / \mathrm{Pt}, \mathrm{O}_{2} / \mathrm{W}$ など が発表されて以来 ${ }^{34)}$, これ东で述べたものも含め, 相当 数伛なる.わが国でも中村らのすぐれた研究がある ${ }^{35}$.

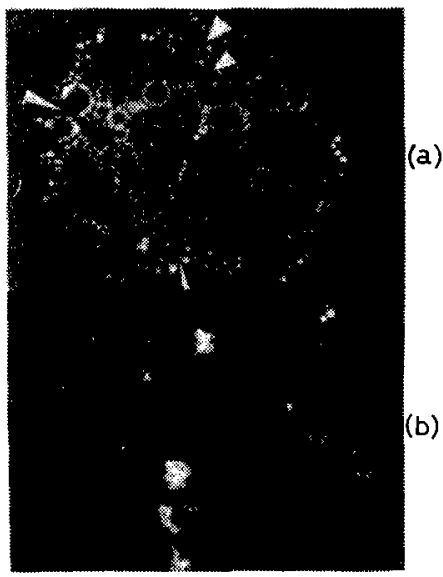

図 9 (a) : 粒界 (細矢印) と表面格子尔陌 (太矢印) の亦るWの He イオン像

(b)：同上試料上に化学メッキされたPtの像(阿 部、屋代，遠藤)
他の研究例としては筆者らによって行われたものがあ 万 $^{36)}$. 化学入ッキの初期過程に招いて, 基体に粒界や格子 久陥があるときはとの近傍に析出することが多いという 結果をえている．図9にそれを示した．また W tip を 空気にふれさせてから酸に浸し微量溶解をさせるとき， 空気中の諸成分の tip 表面一の吸着が，その後の酸溶解 のモードを決定するらしい ${ }^{377,38)}$ 。これらの研究は，直接 に電気化学の基本的問題に関連するだけに，もっと多数 の実験を必要としており，筆者の研究室で引き続き行わ れている. 図 10 亿酸浸後のWのパターン 3 種を揭げた. 最後の例怯，粒界が 1 点に会している所で著しい酸食が 見られる.上記の上うな純化学的研究への応用はこれか らの分野であり，金属陚料が tip に用いられやすい点か

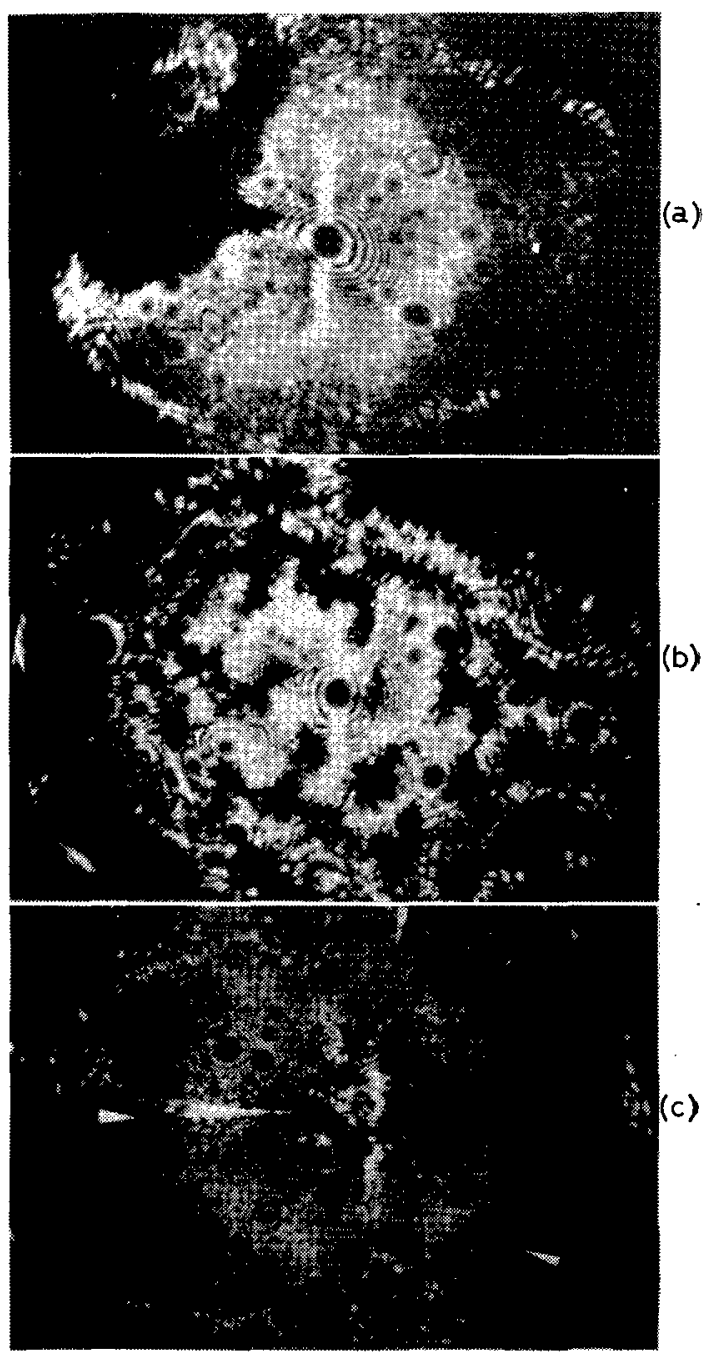

图 $10 \mathrm{HNO}_{3}$ に浸食されたW面（a）:大きな浸食をら けた面，(b)：複雑な浸食をうけた面，(c)：3つ の粒界（細矢印）の交差点で著しい浸食をうけた 面 (屋代，その他) 
ら考えてまず電気化学的分野がもっとも着手しやすい であろう。

\section{6 あとがき}

FIM による最近の研究例のうち，できるだけ本誌に 適した分野を紹介したつるりである.しかし，FIM自体 が主として物理学者の手によって発展させられ，金属学 者もその利用を盛しに進めている現状である.今後法化 学の方面にも, もっと多くの利用, 特に電界誘起化学反 応，高分子の直接観察やその構成原子の配列の決定や化 学結合エネルギーの測定などに進みらる可能性は大き く，筆者の研究室でむそのような指向を持って努力して いる.

\section{文献}

1) E.W. Müller, $Z$. Phsik 131, 136 (1951)

2) J.J. Hren, S. Ranganathan e1., "Field Ion Microscopy" (1968), Plenum.

3) E.W. Müller, T.T. Tsong, "Field Ion Microscopy" (1960), Elsevier.

4) K.M. Bowkett, D.A. Smith, "Field Ion Microscopy" (1970), North-Holland.

5) 屋代雄三, 日本化学会第 27 秋季华会, 総括討論 4, (名古展), 昭柏 47 年10月.

6）营田栄治，中村勝吾，応用物理 31，455（1962）。

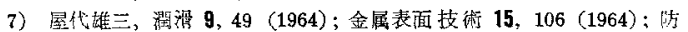
食技街 14, 289 (1965); 金禹表面技術協会絀，“金属表面科学 I”, p. 27 (1969), 朝合書店.

8）日比忠俊，日本金属学会々報 5,82（1966）；11，823 (1972).

9）中村睠吾，応用物理 35，365 (1966)； 41，765 (1972); 固体物理 2, 33 (1967); 日本結盟学会誌 2，33 (1967); 日本金属学会々報 10 , 13 (1971).

10) T.T. Tsong, E.W. Múller, Phys. Rev. Letts. 25, 911 (1970).

11) E.W. Miuller, J.A. Panitz, S.B. McLane, Rev. Sci. Instr. 39, 83 (1968).
12）日本化学会編，“実駼化学講座 14” p. 115 (早川晃雄執筆)（1966）, 丸善.

13) E.W. Muiller, Laboratory Practice 22, 408 (1973).

14) A.J. Jason, Phys. Rev. 156, 266 (1967).

15) E.W. Müller, Ber. Bunsenqles. physik. Chem. 75,979 (1971).

16) R. Lewis, R. Gomer, Appl. Phys. Letts. 15, 384 (1969).

17) P.J. Turner, P. Cartwright, E.D. Boyes, M.J. Southon, "Advan. Electron. Electron Phys." 33B, 1077 (1972), Academic.

18) M.J. Needham, Electronics 14, 117 (1973).

19) E.W. Mtiller, S.V. Krishnaswamy, S.B. McLane, Surface Sci. 23, 112 (1970).

20) E.W. Muller, Naturwiss. 57, 222 (1970).

21) M.G. Inghram, R. Gomer, J. Chem. Phys. 22, 1279 (1954).

22) H.D. Beckey, Z. Naturforsch. 16a, 505 (1961); "Field Ionization Microscopy" (1971), Pergamon.

23) J. Block, Z. physik. Chem. 39, 169 (1963); J. Vac. Sci. Tech. 7, 63 (1970); "Proceed. 5 th Intern. Cong. Catalysis" E91, (Florida) 1972, North-Holland American Elsevier.

24) H.R. Schulten, H.D. Beckey, Org. Mass Spectrom. 6, 885 (1972).

25) W.A. Smidt, O. Frank, J.H. Block, 20th Field Emission Symposium (PSU) Avg. (1973).

26) L.W. Swanson, L.C. Crouser, Surface Sci. 23, 1 (1970).

27) G. Ehrlich, F.G. Hudda, J. Chem. Phys. 36, 3233 (1962).

28) J.F. Mulson, E.W. Mijller, ibid. 38, 2615 (1963).

29) A.A. Holscher, W.H.H. Sachtler, Discuss. Faraday Soc. 41, 29 (1966).

30) E. Sugata, S. Ishii, Sur face Sci. 24, 663 (1971).

31) R.T. Lewis, R. Gomer, Surface Sci. 26, 197 (1971).

32) W. Schmidt, E. Krautz, ibid. 32, 349 (1972).

33) E.W. Müller, R.D. Rendulic, Science 19, 961 (1967).

34) E.W. Müller, "Structure and Properties of Thin Films" ed. by C.A. Neugebauer, J.B. Newkirk, D.A. Vermilyea, p. 476 (1959), J. Wiley \& Sons.

35）中村勝吾，足立敏之，黑目司，灾用物理 37，526（1968）

36) 阿部哲夫，屋代雄三，遥藤陽子，金属表面技術 21，291（1970）.

37）屋代婎三，弓矢正治，高山寛，三宅健二，前村治美，金属表面技街 協会第 44 回学術講谈大会 (名古屋) 昭和46年11月.

38）森川浩志, 屋代雄三，中部化学糸係学拹会支部連合秋期大会（名古 屋）昭和 48 年 10 月. 